\title{
nature
}

6 May 2004 Volume 429 Issue no 6987

\section{Carbon impacts made visible}

Despite disagreement between governments about tackling climate change, initiatives are bubbling up from below. With help from researchers and the markets, citizens can be made more aware of how to help reduce carbon dioxide emissions.

E uropeans are well aware of the need to improve their responses to extreme weather. After the floods, heatwaves and droughts of the past five years, many governments and regions are developing their capacity to issue forecasts and heighten the alarmingly poor awareness of citizens both of their vulnerability and of what to do in the event of catastrophes. They are also spending big money on protecting natural systems to mitigate the effects of peaks in rainfall and spells of high temperature, both of which are on the increase.

The case of the River Tisza in eastern Europe, which experienced an unprecedented series of floods in 1998-2001, highlights how far some regions have come. A high level upstream in 2000 gave Hungarians two weeks' notice of a potentially disastrous rise downstream, requiring more than a million sandbags to be laid every day to stop the countryside flooding. As reported at a meeting hosted by the Environmental Protection Agency of Ireland in Dublin last week to assess the effects and communication of climate change, a $€ 500$-million (US\$600-million) development plan and awareness campaign is in place, including the construction of water-retention basins. Similar developments in Poland, Britain and elsewhere are complemented at a European level by large-scale modelling by the Joint Research Centre, intended to provide longer-term warnings of threats.

So far, so impressive. But few of the national initiatives have been placed within a framework of decadal climate trends. Perhaps this is not surprising given that regional climate models are still full of uncertainties. But this only underlines the key challenge: how to convince citizens to do their bit to moderate the unimaginably enormous scale of mankind's carbon dioxide emissions.
Whether or not the Kyoto Protocol is ratified, at least two bottomup opportunities must be grasped. One lies in the Kyoto-inspired, but not necessarily Kyoto-dependent, market for emissions trading (see Phil. Trans. R. Soc. A, August 2002 special issue). A combination of a voluntary domestic market in the United States, European Union initiatives, and national and state schemes worldwide has yielded a rapidly growing but still pitifully small market, currently trading some 70 million tonnes of carbon dioxide per year. The extent to which such schemes can alleviate emissions without Kyoto-like treaties is not clear. But they can lead to a change in habits as awareness of the costs of carbon emissions permeates through the companies, organizations, regions and investors involved. A key step is to incorporate air transport, land use and carbon sequestration into trading frameworks. This should reduce the inequities, especially if they allow the developing world to profit more sustainably from its natural resources.

Advocates of responsible behaviour must seize every opportunity to get their message across, such as the forthcoming ice-age blockbuster The Day After Tomorrow, due for release worldwide on 28 May. The film's website shows how to offset the carbon impact of your climatologically reckless lifestyle. Climatologists will criticize the faulty science on which the film is based, but it will allow them to raise citizens' awareness of the state of climate and ocean science and, moreover, to heighten carbon consciousness. Climate researchers should contact their local media, who will seize the chance to trade on a disaster movie while tapping into the public fascination with science. If, as a result, the graph of carbon dioxide's atmospheric increase can be seen as our era's ticking clock, so much the better.

\section{Ethics of therapeutic cloning}

\section{A moment of triumph for South Korean science appears to have been marred by doubts about lab practice.}

T herapeutic cloning is one of the most divisive topics in modern biology. To some, it promises a future in which damaged and diseased tissues and organs will be replaced without worrying about immune rejection. To others, the idea of creating a human embryo and culturing it for several days to obtain stem cells that would be needed to grow such grafts is morally reprehensible. The two sides have been battling it out in legislatures across the world over the past few years.

The last thing those engaged in therapeutic cloning research need, therefore, is further ethical controversy. Yet a storm seems about to break over the field's most prominent paper to date — the report in February that a group in South Korea had derived a line of embryonic stem cells from a cloned human embryo (W. S. Hwang et al. Science 303, 1669-1674; 2004). Questions are being raised about how the researchers managed to recruit so many women prepared to donate their eggs for the project. One such question is why a $\mathrm{PhD}$ student, who was a co-author on the paper, initially told Nature she was an egg donor but later changed her story (see pages 3 and 12).

In the context of South Korean society, it's easy to see how students involved in such a project might, with the best of intentions, want to donate their eggs. Korea is an intensely patriotic country, in which the desire to help others is deeply ingrained. The prospect of helping sick patients, and demonstrating that Korea is capable of world-leading research, would be a powerful motivating factor. In such circumstances, say bioethicists, procedures should be in place to ensure that the donors are all volunteers with no direct connection to the research. The principal investigators must now demonstrate that such safeguards were in place, and that they were rigorously applied.

Questions should also be asked of the local Institutional Review Board (IRB) that gave ethical approval for the research project. IRBs are supposed "to assure, both in advance and by periodic review, that appropriate steps are taken to protect the rights and welfare of humans participating as subjects", according to the US Food and Drug Administration. So far, the IRB that approved the Korean cloning project has been less than forthcoming about its work.

If the air is not cleared quickly, the consequences for Korean science - and for research into therapeutic cloning internationally could be severe. It will be a tragedy if one of the greatest scientific stories of the year ends up being remembered, in South Korea especially, as one that lost the trust of the people. 